\title{
Общеобразовательная школа и земство в России. Вторая половина XIX - начало XX вв.
}

\begin{abstract}
Аннотащия. Статья посвящена деятельности земств в сфере народного образования. Рассматриваются отношения органов местного самоуправления с властью, изменение взглядов земиев на задачи теоретической и практической работы, на ихучастие в Финансировании этой области. Обращение к данному сюжету позволяет выйти на более обшие проблемы - развитие народного образования в пореформенное время, роль земства в создании нового типа народной школы, взаимоотномения власти и общества. Важным событием в начале ХХ в. стала попытка введения всеобщего начального обучения. Позииия правящих кругов во многом определялась степенью активности общественных сил. Наиболее радикальный проект введения всеобщего начального обучения был разработан в Министерстве народного просвещения в 1905 г. - в период относительного равновесия сил революиии и власти. По мере укрепления позищии власти степень радикальности министерских чиновников снижалась, сокращалось финансирование земских программ. В результате проблема всеобщего начального обучения окончательного разрешения не получила, однако 50-летняя деятельность земств в области народного образования принесла определенные плоды, повысив уровень грамотности сельского населения.
\end{abstract}

Ключевые слова: культура России, рубеж веков, икольнал реформа, образовательная политика, Министерство народного просвещения, земство, местное самоуправление, власть, просвещение народа, отночение общества.

Abstract. This article is devoted to the activity of the Zemstvo in the sphere of public education. The author reviews the relation between the organs of local government with the central authorities, the changes in local governments regarding the problems of theoretical and practical works, and their involvement in financing this sphere. The study of this topic allows to enter the wider discussion concerning the question of public education in the post-reform period, the role of the Zemstvo in the formation of a new kind of public school, and the relationship between government and society. The attempts at introducing a general primary education became one of the most important events of the early 20th century. The position of the ruling circle was significantly determined by the mobilisation of social forces. The most radical project of introducing a general primary education was developed by the Ministry of National Education in 1905 - during the period of the relative equilibrium between revolutionary forces and the government. With the strengthening of the government's position the degree of radicalisation among the ministry officials subsided and the budgets of local programs were cut. As a result the question of the general primary education had not been resolved, but the 50-year activity of the Zemstvo in the sphere of public education nonetheless bore its fruits having increased the level of literacy in the rural population.

Key words: local self-government, zemstvo, Ministry of National Education, educational policy, school reform, turn of the century, Russian culture, authorities, public education, attitude of society.

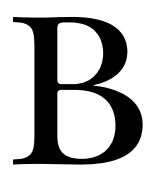
2014 г. исполнилось 150 лет реформам, в результате которых в России появились земства - органы местного самоуправления, - а также система народного образования, просуществовавшая в стране с некоторыми модификациями до 1917 г. Важной проблемой, неразрывно связанной как с историей земства, так и с развитием образования, является деятельность земств, представителей либеральной и демократической интеллигенции в сфере просвещения народа.
Литература по этому вопросу весьма обширна. В работах исследователей конца XIX начала XX вв., некоторые из которых сами были земцами, педагогами-теоретиками и практиками, членами комитетов грамотности, педагогических обществ и пр., изучалась деятельность органов местного самоуправления в области народного образования, их социальный состав, взаимоотношения с официальной властью.

Сведения обобщающего характера о земствах приведены в четырехтомном труде Б. Б. Веселовского [1]. В частности, исследова- 
Социальная история

DOI: $10.7256 / 2222-1972.2015 .4 .17036$

тель, говоря о стремлении правительства усилить в 1890-е гг. представительство дворянства и его роль в земствах, отмечает, что по мысли властей это должно было оказать влияние и на развитие народного образования. Однако, по его мнению, к этому времени изменилось само дворянство: «выдохлись крепостнические традиции», отношение дворянства к образованию народа стало более активным по сравнению с деятелями «всесословных» земств 1860-х гг. [1, т. 1, 485].

Богатый фактический материал о деятельности земств содержится в работах региональных исследователей, отразивших развитие народного образования в земских губерниях России. В этих исследованиях обращается внимание на изменение сословного состава земств, эволюцию взглядов земцев различных «призывов» на работу в сфере просвещения народа, их роль в организации школьного дела «на местах» в новых условиях пореформенной России. Направление и результативность этой работы обусловливались как взаимоотношением земств с властью, так и изменявшимися с течением времени взглядами самих земцев $[2 ; 3 ; 4 ; 5 ; 6 ; 7]$.

Много внимания в этих работах уделялось также учительству: подготовке его кадров, роли земств в этом процессе, изменению социального портрета, материальному и правовому положению этой части интеллигенции, деятельности земских учителей, представителей либеральной общественности, работавших в комитетах грамотности - важной составной части общественно-педагогического движения. Позиции представителей власти, в том числе и в отношении земств, освещены в работах П. Н. Милюкова [8], С. И. Миропольского [9], С. В. Рождественского [10] и др.

Работы советских историков, изданные в 1950-1980-е гг., богаты материалами о деятельности земств, в чем-то перекликающимися с данными Веселовского, позволившими ему сделать интересные наблюдения о их работе в 1890-1900-е гг. Однако историки середины ХХ в. в оценке просветительской деятельности земств не смогли отойти от принятого в то время классового принципа. Они писали о более активной работе в сфере образования тех органов местного самоуправления, где было «больше представительства от крестьян». Деятельность земств с более «дворянским составом», по мнению этих авторов, «отмечена снижением уровня просветительской работы», являвшейся «вялой оппозицией правительству» $[11,71 ; 12,68]$.
В 1990-2010-е гг. вышли работы, написанные на материалах местных архивов. В этих исследованиях даются более объективные оценки позиции представителей власти, либеральной общественности, значительно больше внимания уделяется роли земств в развитии народного образования $[13 ; 14 ; 15 ; 16 ; 17]$.

Изучение земской деятельности продолжается. В апреле и декабре 2014 г. в МГУ имени М. В. Ломоносова состоялись две международные научно-практические конференции, посвященные юбилею земской реформы, - «Земские учреждения и местное самоуправление: История и современность. К 150-летию учреждения земств в России» и «Институты гражданского общества и местное самоуправление в России». Были заслушаны доклады, освещающие различные аспекты деятельности земств в широком пространственном диапазоне. Вопросы, затронутые в предлагаемой читателю статье, частично были освещены в докладах автора на этих конференциях: «Земство и народное образование» и «Попытка введения в России в начале XX в. всеобщего начального обучения: земство и власть».

Важными источниками по развитию школы в связи с деятельностью земств являются статистические описания состояния народного образования в губерниях, изданные в конце XIX - начале XX вв., а также сохранившиеся в Центральном историческом архиве Москвы (ЦИАМ); материалы Первой всеобщей переписи населения России 1897 г. [18; 19; 20; 21; 22; $23 ; 24 ; 25 ; 26 ; 27]$. Данные по регионам страны включают сведения о функционировании школ различного типа и ведомственной принадлежности. Эти сведения позволяют сделать вывод о качественном отличии земских училищ от министерских начальных учебных заведений и церковно-приходских школ. Отмеченное отличие заключается в большей результативности работы земских училищ и популярности у населения (количество учащихся, уровень даваемого первоначального знания и методика обучения, число оканчивающих полный курс и пр.).

Материалы переписи позволяют проанализировать итоги развития народного образования в XIX в. - прежде всего количество грамотного населения в сельской местности по полу, возрасту и сословиям. Эти сведения важны для выяснения әффективности работы народной школы в пореформенной России, степени доступности демократическим слоям начального образования. Можно сделать выводы, с одной 


\section{Исторический журнал: научные исследования № 4 (28) • 2015}

\section{DOI: $10.7256 / 2222-1972.2015 .4 .17036$}

стороны, об огромной заслуге пореформенной школы, поднявшей уровень грамотности в стране, и роли земств в налаживании работы школ, а с другой - о сохранявшейся актуальности проблемы введения всеобщего начального обучения, поставленной общественностью в начале нового столетия.

$$
* * *
$$

Освободившееся от крепостной зависимости крестьянство было в подавляющем большинстве неграмотным: в середине XIX в. число грамотных в сельской местности составляло всего 2\% [28, 37]. Либеральная и демократическая общественность, представители которой, наряду с дворянством, входили в состав земств, увидела свой долг в просвещении этой многомиллионной массы крестьянства.

При подготовке положения о земствах общественностью отдельных губерний высказывались предложения о передаче земствам права заведования начальными учебными заведениями. Правительство в лице Министерства народного просвещения, подготавливая школьную реформу 1864 г., также поставило вопрос о степени участия земств в деле просвещения народа. В частности, некоторые представители власти допускали возможность предоставления земствам широких полномочий в управлении школами. В положении о начальных училищах 1864 г. предусматривалось привлечение к этому делу общественных сил. Однако в дальнейшем предложения относительно прав земств были отклонены с мотивировкой: не следует расширять компетенцию земств больше, чем предполагалось по положению о них 1864 г. [10, 447-450; 1, т. 1, 449]. В результате, по заключению одного из исследователей деятельности земств, они допускались «к добровольному участию в доставлении средств на первоначальное образование» и наблюдению за ним посредством работы в училищных советах, к «участию преимущественно в хозяйственном отношении и в пределах, законом оправданных, в попечении о народном образовании. По существу, все дело находилось в руках бюрократических инстанций» [29, 445].

Образование и здравоохранение являлись областями работы земств, которые изначально были объявлены «необязательными», в отличие от расходов и работ по содержанию богаделен, тюрем, обеспечению строительства дорог, постоя войск и пр. Однако в реальной жизни именно эти сферы стали наиболее важными для местных органов управления - как по части их финансирования из земского бюджета, так и по вкладу, внесенному в практическую работу. В реализации реформы общеобразовательной школы 1864 г. важнейшая роль принадлежала земствам. Однако взгляды земцев на задачи их деятельность в этой сфере, как и сама работа, развивались постепенно.

До середины 1890-х гг. губернские земства отстранялись от финансирования начальных училищ, вменив это в обязанность уездным земствам. Инициатива наиболее передовых губернских управ (Ярославской, Тверской, Черниговской, Вятской) о расширении их участия в школьном деле поддержки не встретила [1, т. 1, 462].

В первый «призыв» входившие в состав уездных земств дворяне являлись помещиками «старого закала» - бывшими владельцами крепостных. Они считали, что образование народа - это дело самого народа. Земские деятели в лице даже лучших своих представителей исповедовали принцип: «Образование должно быть общественным, т. е. общедоступным <...> осуществляемым на общественные средства» [29, 448]. Поэтому в первые годы ассигнования земских уездных управ на образование были незначительными. В 1868 г. из 324 уездных управ более одной трети не выделяли средств на народное образование. Уездные земства, отчислявшие их, начальным школам для народа уделяли минимальную часть [1, т. 1, 459]. Для этого времени было характерно увлечение дешевыми школами, и практическая деятельность земств свелась в основном к поддержке существовавших церковно-приходских школ и «поощрению» сельских обществ, носившему, впрочем, бессистемный характер. При отсутствии точной цели вложения субсидий деньги тратились на разовые выплаты учителям и ученикам [1, т. 1, 462].

Более важной была теоретическая и организационная работа. В 1860-е гг. у земцев - представителей педагогической общественности еще не было четких представлений о задачах народной школы. Велись споры о том, какими должны быть даваемые ею знание - профессиональным или общеобразовательным - и воспитание - светским или религиозно-нравственным. Все положительное, что было сделано земствами в эти годы, связано с работой земских педагогов по выработке нового типа народной школы, с подготовкой учителей. Оценивая и характеризуя эту деятельность, публицист Н. В. Шелгунов писал: «Это была большая и 
сложная работа. Россия, никогда не слыхавшая об ученых педагогах, о методах и педагогии <...> создала ряд даровитых, знающих и фанатично преданных делу народного образования писателей, воспитателей, учителей, создавших никогда еще не слыханную в России педагогию и установивших народную школу на научных основаниях» $[30,228]$.

Важным моментом в этой деятельности стала разработка и внедрение новой методики обучения, ставившей во главу угла сознательное (в отличие от распространенного механического) восприятие учениками знаний. Программу общеобразовательного знания старались облегчить, сократить за счет изъятия грамматических форм, которые «не развивают ученика, а быстро стираются из памяти» как невостребованные в практике реального крестьянского труда и быта. «Приспособление программ и методики к особенностям сельской жизни придало им национальную окраску» [31, 133-134].

Другим начинанием, менявшим методику обучения, стало снабжение народных школ наглядными учебными пособиями. «В 60-е годы не допускалась даже мысль о наличии пособий <...> Теперь были, хотя и потрепанные, географические карты, атласы, глобусы, арифметические пособия по обучению счету, складная сажень, подвижные азбуки. Это был большой шаг вперед» [32, 243]. Новой методике учителей обучали на педагогических курсах, в учительских семинариях, открывавшихся на средства губернских земств.

В ходе практической работы школ решался вопрос о целесообразности профессионализации начального обучения. Н. Ф. Бунаков - педагог, долго работавший в министерских училищах на селе, создавший в 1867 г. свою начальную школу, - на основе многолетнего опыта общения с народом пришел к выводу, что крестьяне не желают ни профессионального, ни практического обучения: «между крестьянами нет и речи, чтоб школа учила пахать, хлебы печь или какому-нибудь ремеслу», от школы ждут «настоящей грамотности», придавая ей очень широкое значение - «от хорошего учителя дети научаются жить совестливее, разумнее» [3, 269-270]. По мнению Н. Ф. Бунакова, практический взгляд крестьян на грамоту был далек от узкого практицизма, навязываемого народной школе сверху.

Бунаков был не одинок в своих выводах. Большой вклад в создание школы нового типа внес К. Д. Ушинский. Энциклопедически обра- зованный человек, он преподавал в Демидовском лицее в Ярославле, работал инспектором в Гатчинском сиротском приюте и Смольном институте. Ушинский написал учебники «Детский мир», «Родное слово», по которым учились несколько поколений детей, издал руководства для учителей сельских школ. По его мнению, после реформы все более нужными для народа становились школы, вносившие «умственное развитие, которое бы научило употреблять с пользой для себя и других свою свободу» $[2,24 ; 33,607,625]$. В связи с этим задачей учителя было «вносить не одно знание грамоты, а умственное развитие, образование и те гражданские правила жизни, на которых покоится благоденствие государства» $[2,24]$. Усилия общественных деятелей нового поколения в просвещении народа противостояли политике правительства, пытавшегося профессионализировать начальное образование. Однако использование земскими учителями методов наглядного обучения придавало сельской школе более практический, приноровленный к условиям крестьянского быта характер.

Начиная с конца 1860-х гг. в земствах нового «призыва» стали работать люди более прогрессивных убеждений, с иными, в том числе и у дворян, воззрениями на народное образование. Его финансирование уездными земствами стало неуклонно возрастать и вскоре превратилось в одну из основных статей расходов. Уже в 1869 г. в некоторых губерниях они увеличились в 1,5-3 раза [34, 192]. В 1868-1875 гг. затраты уездных земств на начальную школу превысили уровень затрат любого центрального ведомства [35, 25]. Постепенно отходя от прежнего убеждения, что образование народа есть дело самого народа, земства с 1870-х гг. стали принимать на себя часть расходов по содержанию учителей, с 1880-х гг. - освобождать сельские общества от затрат на содержание школьных помещений [1, т. 1, 463]. К середине 1890-х гг. в ведении земств (в том числе и финансовом) находилось 60-80\% сельских школ $[36,30 ; 14,29 ; 21,29 ; 22,12]$. В 18701880-е гг. земства стали отходить от практики поддержки церковно-приходских школ. Теперь средства в значительной степени вкладывались в открытие новых земских школ, в снабжение их учебными пособиями, в оплату труда учителей, подбор кадров преподавателей. Продолжали открывать педагогические курсы для сельских учителей, организовывать учительские семинарии.

В некоторых губерниях уже 1870-е гг. стали переломными в создании сельской школы, 


\section{Исторический журнал: научные исследования № 4 (28) • 2015}

\section{DOI: $10.7256 / 2222-1972.2015 .4 .17036$}

в которой элементы светского обучения превалировали над религиозным знанием: расширился круг даваемых ею общеобразовательных сведений, возросло число учителей со специальной педагогической подготовкой, пришедших на смену выпускникам духовных семинарий $[4,118 ; 14,21 ; 13]$. Таким образом, земская народная школа, в отличие от церковно-приходских школ, также предназначавшихся для народа, постепенно складывалась как общеобразовательное светское учебное заведение.

Важным моментом было принятие земствами на себя расходов по содержанию учителей. Это способствовало улучшению материального положения учительства, до того полностью зависевшего от сельских обществ. Очень часто крестьянство смотрело на учителей враждебно именно потому, что обязано было их содержать. Учителя часто не получали жалованья, в летнее время его не платили вообще, в учебный период оклады были мизерными (нередко менее 100 руб. в год или 5 руб. в месяц $[37,34])$. Это приводило их к унизительной зависимости от населения, что не способствовало авторитету учителя и, как следствие, доверию к школе. В некоторых губерниях земства практиковали прибавку к основному жалованью учителя, доводя его оклад до 300 руб. в год, введение права на получение земской пенсии в зависимости от выслуги лет от одной до двух третей жалованья [38, 124]. Создав для учителя материальную и общественную поддержку, земства способствовали поднятию престижа учителя «до уровня общественного работника» $[5,18]$, что способствовало росту у населения авторитета школы.

Внимание земств привлекали также крестьянские - так называемые вольные - школы грамоты, распространенные в деревнях, где еще не было правильно организованных училищ. Эти школы давали элементарную грамоту путем обучения крестьянских детей учителями-самоучками по Часослову или Псалтири, без использования какой-либо методики. Такие школы не имели собственных помещений, занятия проходили в крестьянской избе с количеством учеников в пределах десятка. Оплата учительского труда была обычно в натуральной форме - за «прокорм и ночлег».

Включение этих школ в орбиту внимания земств способствовало упорядочению их работы: земства направляли туда учителей, имевших специальную подготовку или хотя бы общее образование не ниже среднего, снабжали учебни- ками, пособиями, школьными принадлежностями. Уровень обучения деревенских детей стал постепенно меняться к лучшему. Опека земствами школ грамоты беспокоила правительство. При всех колебаниях образовательной политики власти старались не изменять некоторых ее принципов. В частности, их отношение к начальному обучению крестьян базировалось на принципе «возможно большего сокращения образовательного значения народной школы» [39, 91]. Пытаясь оградить школы грамоты от влияния прогрессивных сил, в 1891 г. их передали в ведение Синода с усилением в них религиозного элемента обучения.

Один из зарубежных исследователей российской глубинки - профессор Чикагского университета Э. Гумп - высказал суждение, что деятельность земств в 1870-е гг. имела чисто формальный характер [40, 306]. Однако подобная оценка искажает реальные факты, так как материальная поддержка работавших учителей, повышение их квалификации, подготовка новых кадров для школы имели далеко не формальные последствия. Не учитывать этого - значит недооценивать роль общественности в важнейшем деле образования народа.

В своей деятельность земства постоянно наталкивались на сопротивление властей. В 1874 г. была создана школьная инспекция, ставившая под жесткий контроль работу земских школ, деятельность учителей, работавших по новой, разработанной земцами методике преподавания. В период переоценки Великих реформ в 1880-1890-е гг. представительство дворянства в земствах было увеличено и его роль усилена. Правительство считало, что только дворянство способно повести образование народа в нужном властям направлении, обеспечивающем упрочение существующего строя и воспитание крестьянства в духе религиозной нравственности [41, с. 4-5]. Училищными советами, ранее возглавлявшимися педагогами, теперь руководил предводитель дворянства; возросла роль губернатора, который мог не соглашаться на открытие земских училищ, на назначение земских служащих, в том числе учителей $[29,445]$. В 1880-е гг. при активной поддержке государства насаждались церковно-приходские школы, и под давлением властей в земских училищах несколько замедлилось расширение светских элементов обучения, ужесточился контроль инспекции за уровнем религиозно-нравственного воспитания в них. 
Однако не все замыслы правительства воплощались в жизнь. К этому времени изменилось само дворянство. По замечанию Веселовского, «дворянские земства были меньше проникнуты духом сословности, чем “всесословные” земства 60-х годов» [1, т. 1, 485]. Именно в 1890-е гг. активизировалось участие губернских земств, состав которых был чаще дворянским, в финансировании начального образования; прекратилась поддержка уездными земствами церковно-приходских школ, признанных наносящими вред духовному здоровью молодого поколения [1, т. 1, 489-490].

Педагогами - теоретиками и практиками К. Д. Ушинским, Н. А. Корфом, Н. Ф. Бунаковым и др. был выработан новый тип народной школы, учитывавший национальные особенности жизни, приближенный к нуждам крестьянства: установлена минимальная продолжительность курса - три года, - разработан и внедрялся в практику звуковой метод обучения грамоте, существенно ускорявший овладение чтением и письмом. Земская школа по объему курса приравнивалась к приходскому училищу, и в ее программе официально не было даже начал общего знания. Однако земские педагоги разработали, а сельские учителя осваивали методику объяснительного чтения. На этих уроках читались специальные пособия, в которых сообщались некоторые сведения из истории, географии, о природе, развитии человека и общества. Даже изучение Закона Божьего - предмета, обязательного и в земской школе, - принимало иной характер: построенные на принципах наглядности уроки по этому предмету были далеки от механического заучивания молитв - метода, распространенного в школах духовного ведомства. Крестьяне отмечали, что дети приносили домой сознательную веру, приобщали к ней и взрослых членов семьи. Выпускники земских школ овладевали практически полезными знаниями и умениями, у многих возникало желание расширить свой кругозор путем самообразования [3, 270-272; 38, 129].

Уже в конце XIX в. земства поставили вопрос о расширении курса начальной школы до четырех лет. Важной особенностью новых школ была созданная в них нравственная атмосфера, основывавшаяся на уважении личности ученика.

Земская школа была принята крестьянством. Это подтверждается фактом сокращения числа школ грамоты там, где были земские школы. В Тверской губернии, например, в
1912/1913 учебном году их число уменьшилось в 4 раза (с 245 до 59). В Ярославской губернии в 1915 г. осталось 6 школ грамоты (в 1900-е гг. их было более 200 - 20\% от общего числа школ). Сокращалось число учащихся в церковно-приходских школах и школах грамоты. Крестьяне даже в случае отдаленности земского училища предпочитали отдавать детей в него, а не в расположенную поблизости церковно-приходскую школу. По сведениям из губерний, земские школы отличались большим числом учащихся (100 и более чел.), в них обучались более половины крестьянских детей (в церковно-приходских школах - 15-20\%, в школах грамоты - 4-6\%) $[42,7 ; 43,21 ; 23,17,23,24 ; 22,20,24 ; 4,116 ; 36$, $4,5]$. В уездные управы все чаще поступали ходатайства и «приговоры» сельских обществ об открытии у них земских, а не церковно-приходских школ; крестьяне готовы были брать на себя хозяйственные расходы: по найму, отоплению и охране школьных помещений [29, 467].

Заинтересованность крестьян в земской школе объяснялась тем, что обучение в ней было подчинено интересам крестьян, помогало им сознательно использовать навыки, полученные в практике повседневной работы.

Испытанием для всего российского общества стали годы первой русской революции. События тех лет способствовали поляризации общественных сил. Вместе с тем для крестьян они стали мощным катализатором в осознании ими необходимости грамотности. В Государственном архиве Российской Федерации отложились сообщения из губерний о настроении населения, поступавшие в Министерство внутренних дел. В них отмечалось: «деревня сильно развивается», «мужик начинает просыпаться и внимательно прислушиваться к далекому рокоту общественной жизни», «у крестьян сильно осознание необходимости всеобщего образования, громадный спрос на газеты», «крестьянский сход вынес приговор о всеобщем обучении», «при финансовом кризисе земства крестьяне лично ассигновали 4 тыс. руб. на повторные уроки (имеются в виду классы для занятий со взрослыми. - E. C.). Земство относилось к этому отрицательно, но крестьяне настояли на своем».

Учительство в своей просветительской деятельности заняло более активную, часто более политизированную позицию. Тем не менее, по данным МВД, отовсюду сообщали об изменении к лучшему отношения к учителю со стороны населения: «Отношение крестьян к учителям 


\section{Исторический журнал: научные исследования № 4 (28) • 2015}

DOI: $10.7256 / 2222-1972.2015 .4 .17036$

хорошее: они видят в учителе солидарного [с ними] по оппозиционному к властям отношению». Или: «Если раньше хотели сжечь школу, учителя убить, то теперь школа стала клубом для крестьян, а учитель - советчиком» $[44$, л. 1$]$.

Земцы по своим взглядам были близки к кругам либеральной буржуазии. Как известно, российская буржуазия после Манифеста 17 октября 1905 г. изменила свое отношение к дальнейшему развитию революционного движения. Этого не избежали и земцы.

По данным Департамента полиции, в районах более активных крестьянских выступлений отношение земства к учительству резко ухудшилось. Учителей называли негодяями, крамольниками, подстрекателями, считая, что их сближение с населением «развивает крестьян», т. е. революционизирует их. Были случаи невыплаты земствами жалованья учителям с мотивировкой: «Вы выступали за невыплату налогов, вот и сидите без жалованья». Напротив, в более спокойных регионах отношения были прежними $[45$, л. $1,5,7,8,9]$.

События революции изменили и крестьянство, и учительство. В послереволюционные годы крестьянство при всем доверии к земским школам по сравнению с церковно-приходскими школами стало предъявлять земским училищам более высокие требования, ставя вопрос о расширении курса, включении в него общеобразовательных предметов.

Одним из последних по времени мероприятий, которое земства пытались провести в сфере народного образования, стала попытка введения в России в начале XX в. всеобщего начального обучения.

Вопрос о нем обсуждался как в правительстве, так и в обществе еще при подготовке реформы образования. Некоторые земства ставили его позднее - в 1870-е гг., поднимался этот вопрос и в начале 1890-х гг. Однако практических мер в то время не предпринималось, так как, по общему мнению - как властей, так и общественности, - число школ было столь невелико, что не позволяло дать гарантию получения начального образования всеми детьми школьного возраста. Это снимало вопрос о всеобщности начального обучения, тем более о его обязательности.

В начале XX в. в условиях модернизации страны неграмотность большинства населения стала ощущаться более остро. В 1900 г. Министерство народного просвещения узаконило сложившийся на практике трехлетний курс на- чальной школы. Но это было мерой вчерашнего дня, так как еще с 1890-х гг. земства ставили вопрос об увеличении курса начального обучения до 4-х лет, ходатайствовали о расширении программы начальной школы. Сельская школа, в которой обучалась основная масса населения крестьянство, - продолжала оставаться преимущественно низшей, с курсом элементарного знания в 3 года, реже - в 4 года, а еще реже - повышенной, с курсом в 5 лет. Но и такое знание не всегда было доступно народу.

Данные обследований свидетельствовали, что и в начале $\mathrm{XX}$ в. количество обучающихся детей школьного возраста (8-11 лет) не превышало $35 \%$, вне школы оставались более $64 \%$ детей $[46,14 ; 19,175]$. В одной из наиболее грамотных губерний - Ярославской - в $19 \%$ селений дети не пользовались школой. В земских губерниях при довольно развитой сети народных школ в среднем на 100 жителей приходилось 3,1 учащегося, в других губерниях этот показатель был еще ниже [21, 119; 22, 37]. Даже в регионах с наибольшей грамотностью - европейских в середине 1890-х гг. одно училище приходилось более чем на полторы тысячи жителей. Это было результатом, среди прочих обстоятельств, и сохранявшегося до сих пор недостатка школ.

Отставание России от стран Западной Европы и США в числе грамотных становилось все более очевидным: в США из каждых 100 жителей в школе обучались 22 человека, в Швейцарии и Германии - 19, в Англии - 16,6, во Франции - 12, в Испании - 8,4, в Болгарии - 5,4 человека [22, 38]. В Европе проблема всеобщего начального образования была решена еще в конце XIX в. Оно там представляло собой 7-8-летнее обучение [47, 171].

Меры по введению всеобщего обучения активно обсуждались на съездах педагогической и земской общественности. В 1900-е гг. расширился круг педагогических изданий, обсуждавших его. Развернулась подготовительная работа по введению всеобщего обучения. Комитеты грамотности подготовили свои записки и проекты. С 1895 г. губернские земства взяли на себя роль центра, объединявшего усилия в этом направлении: руководили местными исследованиями по установлению школьных сетей, т. е. выявлением числа правильно организованных школ, оценивали их соответствие требованиям начального обучения, а также проводили учет детей школьного возраста, не посещавших школу. Земские собрания единодушно высказывались против понижения образовательного уровня народных 
училищ, включавшихся в школьную сеть, считая, что церковно-приходские школы и школы грамоты, находившиеся в ведении Синода, по объему даваемого знания не соответствуют запросам народа. Они также выступали за расширение сети школьных и народных библиотек, необходимых для реализации проекта всеобщего обучения, так как знания, полученные в школе, без чтения быстро утрачивались [29, 467-470].

Власти были озабоченны такой активностью общественности. Стремлением не упустить инициативу из своих рук и удерживать контроль над процессом объясняется то, что в министерских кругах начал разрабатываться проект введения всеобщего начального обучения. Однако властями он рассматривался как возможное орудие наступления на права земств. Согласно одному из первых проектов министерства, земства лишались всех прав влияния на школу, кроме права выделять средства. После предварительного обсуждения проекта в Московском учебном округе он одобрен не был. Дальнейшие работы были приостановлены в связи с начавшейся Русско-японской войной.

В период революции 1905-1907 гг. требование введения всеобщего начального обучения стало лозунгом политических партий и союзов. Не только социал-демократическая партия, но и буржуазные, мелкобуржуазные партии, даже некоторые монархические организации, стремившиеся к популярности в массах, включали его в свои программы. И хотя каждый вкладывал в этот лозунг свое понимание, правительство не могло не отреагировать на это единодушие.

В правительстве С. Ю. Витте Министерство народного просвещения возглавил один из образованнейших людей того времени И. И. Толстой, выгодно отличавшийся от своих предшественников на этом посту широтой взглядов. Он признал, что ближайшей задачей школы является «достижение всеобщей грамотности, т. е. получение минимума знаний, который позволит в дальнейшем расширить его путем школьного или внешкольного образования» $[48,114]$.

Разработанный в этот период новый министерский проект введения всеобщего начального обучения допускал паритетное участие правительства и местных органов в формировании школьной сети, давал определенные гарантии, что самостоятельность местных органов «не будет ограничиваться бюрократией». Всем «обществам и организациям, содержащим начальные училища», обещалась ежегодная поддержка от казны - 10,5 млн. руб. Вводились нормы количества учащихся на одного учителя (не более 50 человек), для большей доступности для населения школ одно училище должно было обслуживать район радиусом не более трех верст [49, 4-5].

Однако в связи с изменением политической обстановки в стране, укреплением позиций власти И. И. Толстой был смещен с поста министра, и этот проект не был утвержден. Начался пересмотр его принципиальных положений.

Тем не менее министерство официально признало, что введение всеобего обучения в России есть дело государственное. Это признание было очень важным фактом, так как начиная с XVIII в., когда в стране впервые создавалась система общеобразовательной школы, правительство считало, что финансирование начального образования не должно обременять казну. Содержание создававшихся тогда училищ возлагалось на городские и сельские общества. Этой позиции правительство упорно придерживалось на протяжении более чем ста лет. Только в 1880-1900-е гг. поддержку казны получили школы Синода - церковно-приходские школы. Теперь, когда обучение было объявлено бесплатным и общедоступным для населения всей страны, средства на начальное светское образование обязано было давать казначейство $[18,11]$.

В феврале 1907 г. в Государственную думу поступил министерский законопроект «О введении всеобщего начального обучения в Российской империи». В проект вошли некоторые положения варианта, подготовленного министерством И. И. Толстого. Согласно ему все дети школьного возраста (8-11 лет) должны были получать бесплатное образование в правильно организованной школе. Ее курс составлял четыре года. Число учащихся на одного учителя не могло превышать 50 человек. Каждая школа должна была обслуживать район радиусом не более трех верст. Однако в этом варианте проекта основные расходы возлагались все же на земства и местные общества. Министерство принимало на себя лишь минимальные обязательства по финансированию начальных школ - только содержание учителей: земства, приступавшие к введению всеобщего обучения, ежегодно в виде пособия от казны должны были получать по 360 руб. на одного учителя и по 60 руб. на одного законоучителя. Всеобщее обучение предполагалось ввести в течение 10-12 лет [24, 4-6; 50, 121].

При обсуждении проекта в Думе были сняты положения о бесплатности образования и 


\section{Исторический журнал: научные исследования № 4 (28) • 2015}

\section{DOI: $10.7256 / 2222-1972.2015 .4 .17036$}

четырехлетнем курсе. В таком урезанном виде проект 3 мая 1908 г. получил силу закона. Несмотря на то что Государственный совет его не утвердил, работы по его реализации продолжились. Они показали, что даже там, где открыто нужное число школ, часть детей по-прежнему находятся вне школы. Например, в достаточно благополучном в экономическом отношении Нижегородском уезде в 1908 г. около трети детей не учились $[18,13]$. Безусловно, по сравнению с 1890-ми гг, когда школу посещала только треть детей, это было большим достижением, однако недостаточным для всеобщего обучения. Был сделан вывод, что для его обеспечения только увеличения числа школ было мало. Причиной недоступности школы для всех жителей являлось скудное материальное положение многих крестьянских семей.

Земства разработали меры «по обеспечению пользования населения школами». К ним относились: организация школьного питания (так как дети вместе с дорогой проводили вне дома по 6-7 часов), создание приютов и общежитий для детей из особо отдаленных сел, учащихся железнодорожных школ (например, в 1904 г. на 332 училища этого типа было лишь 70 общежитий, в которых проживали чуть больше полутора тысяч учащихся - $3 \%$ от общего числа обучавшихся в них $[51,123])$, выделение средств на одежду и обувь для малоимущих учащихся, создание в малонаселенных, особенно северных, регионах, районах с хуторскими поселениями передвижных школ [52, 107].

Работа по введению всеобщего начального обучения способствовала осознанию земцами невозможности реализовать эту программу только на общественные средства. Становилось очевидным, что народные школы нуждались в стабильном, гарантированном казной финансировании. Земства ходатайствовали о выделении правительством средств, однако эти ходатайства удовлетворялись казной лишь на одну треть.

В 1909 г. при министерстве был создан Школьно-строительный фонд; отчисления казны в него достигли 10 млн руб. в год. Фонд был предназначен для субсидирования школьного строительства. Однако ссуды не были ни бессрочными, ни безвозмездными: они выдавались не более чем на 20 лет с погашением их при условии 3\% годовых, а получение ссуды оговаривалось рядом условий и требований министерства. В некоторых губерниях, например, выделение ссуды осуществлялось с условием принятия зем- ствами на свое содержание министерских училищ [53, л. 2об.; 54].

Для получения ссуды требовались сведения о финансовом положении учреждения, ходатайствующего о ней, предъявление обоснованной сметы на строительство, утвержденный проект, соответствующий нормам и правилам о школьных помещениях. Однако эти нормы министерством не были опубликованы, что усугубляло в течение последующих лет неразбериху и сложности. В частности, в канцелярию Московского учебного округа из губерний поступали просьбы указать документы, которыми следует руководствоваться при разработке строительных проектов [53, л. 5-5об.]. Все это сдерживало практическую реализацию возможностей фонда.

Таким образом, даже выделяя средства на школьное строительство (подчиняясь принятому Думой закону), чиновники старались создать трудности для их получения и реализации. Разработанная земствами программа по обеспечению пользования населения школами из-за недостатка средств полностью не осуществлялась. В результате проведенной в стране 18 января 1911 г. однодневной переписи начальных школ было установлено, что в сельской местности в среднем по стране школой охвачены попрежнему лишь 30\% детей 8-11 лет, в городе $45 \%$. Приведем минимальные и максимальные данные по учебным округам: в селе - от $23 \%$ (Ставропольский округ) до $43 \%$ (Московский округ), в городе - от $40 \%$ (Ставропольский округ) до $73 \%$ (Московский округ) [55, 28; 56, 23].

Работа по введению всеобщего обучения, ее первые итоги обсуждались на учительских съездах и съездах земских деятелей. В 1911 г. состоялся Первый Общеземский съезд, поставивший ряд вопросов по проблеме всеобщего начального обучения и принявший резолюции, шедшие вразрез с политикой правительства, ограничивавшей доходы земских органов. В частности, в резолюции съезда был включен пункт об отмене закона о предельном земском обложении, существенно сокращавшего доходные статьи земств. В связи с введением всеобщего начального обучения признавалось необходимым предоставить земствам новые источники обложения, освободить их от расходов, имеющих общегосударственное значение, так как введение всеобщего начального обучения неразрывно связано с состоянием их бюджета [57, 6-8].

С трибуны съезда в речах многих ораторовземцев прозвучал протест против включения 
церковно-приходских школ в сеть всеобщего обучения. Это вызвало недовольство администрации съезда, так как правительство считало, что школы Синода наиболее соответствовали решению задач воспитания молодого поколения. Было принято компромиссное решение о включении церковных школ в общую школьную сеть, но с передачей их под надзор училищных советов, а сумм, ассигнуемых Синодом, - в смету министерства.

В резолюциях Общеземского съезда отмечалось также, что без увеличения государственной помощи не менее чем на 10 млн руб. в год всеобщее начальное обучение введено быть не может [57, 100, 107].

Реалии жизни и, в частности, активная позиция общественности и земств заставили министерство увеличивать расходы на начальную школу. Если в 1906 г. на начальное образование выделялась лишь пятая часть министерского бюджета, то к 1913 г. эта доля превышала $40 \%$ бюджета [58, 184; 59, 284].

Общее число школ в стране постепенно увеличивалось. Во многих губерниях к 1910 г. их количество возросло в 1,2-1,5 раза. Так, в Московской губернии было открыто более 100 школ, в Костромской - 150, в Вологодской - около 140, в Пермской - более 150 [1, т. 4, 102]. Общее число школ в стране в 1908-1914 гг. возросло с 50 тыс. до почти 81 тыс., а число учащихся - с 4 млн до почти 6 млн чел. [60, 315].

Реальные сдвиги в школьном строительстве выразились и в том, что если в 1910-1912 гг. более $90 \%$ школьных зданий отапливались, освещались, были оборудованы по старинке, то к 1914 г. уже четверть школ имела электричество, центральное отопление, искусственную вентиляцию, новую мебель [61, л. 3]. По абсолютным показателям это очень незначительное число школ, но все же начало было положено.

Таким образом, в течение 1890-1900-х гг. в развитии российского начального образования произошли некоторые перемены к лучшему. Уже в конце XIX в. число грамотных в России в среднем составляло 21,1\%. Характерно, что наибольшее число грамотных (свыше 60\%) было среди жителей в возрасте до 30 лет - тех, кто обучался в пореформенное время $[20,1,2]$. Эти перемены были обусловлены как изменением отношения народа к школе, так во многом и усилиями земств.
К этому времени в стране функционировало более 17 тыс. земских школ [1, т. 1, 516, 518, 519; 1, т. 3, 391], и количество их продолжало возрастать. Значительная часть крестьян, овладевших грамотой, являлись их учениками. Число грамотных жителей в сельской местности повысилось с $18 \%$ в 1897 г. до 24-25\% к 1910 г. и $37,1 \%$ - к 1917 г. Количество грамотных призывников на военную службу возросло с $37 \%$ в 1897 г. до $65 \%$ в 1910 г. [60, 293, 295, 298; 62, 255]. Несколько расширилась программа начальной школы: в 1910 г. в ее курс как основной предмет была включена история. С 1912 г. стали открываться высшие начальные училища, выпускники которых могли поступать в средние учебные заведения.

Политика правительства в отношении школы имела двойственный характер. С одной стороны, власти осознавали необходимость введения всеобщего начального обучения и неизбежность значительных бюджетных затрат. С другой стороны, налицо стремление власти сохранить традиционные социальные стереотипы, отсрочить социальные, культурные последствия проводимых реформ.

Тем не менее активная позиция педагогической и земской общественности в начале ХХ в. способствовала проведению властью практических мероприятий по разрешению крупных вопросов народного образования, в числе которых было и всеобщее начальное обучение. Но окончательного решения эти проблемы так и не получили - в значительной степени из-за позиции правительства, отвергавшего радикальные перемены в народном образовании.

Однако за 50 лет деятельности земств сфера образования, вопреки намерениям правительства, стала одной из главных в их работе, как по доле средств в бюджете земств, так и по вкладу в организацию школьного дела. Существенные изменения претерпели взгляды земцев на некоторые проблемы развития народного образования, задачи общественности и направления ее работы. Земские педагоги внесли вклад в развитие теоретических проблем начального образования, выработку нового типа народной школы. Можно сказать, что земской школой была заложена основа для распространения грамотности среди сельских слоев населения.

Библиография:

1. Веселовский Б. Б. История земства за сорок лет. СПб.: Издательство О. Н. Поповой, 1909. Т. 1. 724 с.; Т. 2. 703 с.; 1911. Т. 3. 710 c.; T. 4.696 c.

2. Чехов Н. В. Народное образование в России с 60-х годов XIX века. М.: Польза, 1912. 224 с. 


\section{Исторический журнал: научные исследования № 4 (28) • 2015}

DOI: $10.7256 / 2222-1972.2015 .4 .17036$

3. Бунаков Н. Ф. Сельская школа и народная жизнь. Наблюдения и заметки сельского учителя // Бунаков Н. Ф. Избранные педагогические сочинения. М.: Издательство Академии педагогических наук РСФСР, 1953. С. 267-327.

4. Белоконский И. Б. Народное образование в Орловской губернии. К 25-летию земских учреждений // Русская школа. 1890. № 7. С. 112-135.

5. Звягинцев Е. А. Полвека земской деятельности по народному образованию. М.: Задруга, 1915. 96 с.

6. Акимов В. Деятельность Вятского земства по народному образованию (1865-1906) // Журнал Министерства народного просвещения. 1907. № 11. С. 2-46.

7. Акимов В. Деятельность Симбирского земства по народному образованию. (1866-1900) // Журнал Министерства народного просвещения. 1905. № 11. С. 2-35.

8. Милюков П. Н. Очерки по истории русской культуры. Изд. 4-е. СПб.: Редакция журнала «Мир божий», 1905. Ч. 2. 412 с.

9. Миропольский С. И. Школа и государство. Обязательность обучения в России. СПб.: Типография А. Н. Котомина, 1910. 229 с.

10. Рождественский С. В. Исторический обзор деятельности Министерства народного просвещения. 1802-1902. СПб.: Министерство народного просвещения, 1902. 785 с.

11. Очерки истории школы и педагогической мысли народов СССР во второй половине XIX в. М.: Педагогика, 1976. 599 с.

12. Слудковская И. А. Развитие народной школы на Урале в XIX в. Пермь: ПОИПКРО, 1976. 168 с.

13. Балдин К. Е., Иванов В. В. Земские школы Ивановского края: конец XIX - начало XX в. Иваново: ЮНОНА, 2000. 418 с.

14. Иванова Н. И. Деятельность Новоторжского уездного земства по развитию народного образования в 60-90-е гг. XIX в. // Тверская земля в прошлом и настоящем: Сборник научных трудов. Тверь: ТГУ, 1994. С. 24-36.

15. Степанский А. Д. Либеральная интеллигенция в общественном движении // Исторические записки. М.: Наука, 1983. Т. 109. С. 64-94.

16. Сысоева Е. К. Общественность и народная школа в пореформенной России // Вестник МГУ. Серия 8. История. 2002. № 6. C. 16-31.

17. Ястребов А. Е. Народные чтения в губернских городах Центральной России в конце XIX - начале XX вв. (по материалам Орла, Курска, Воронежа) // Общественная и культурная жизнь Центральной России в XVIII - начале XX вв.: Сборник научных трудов. Воронеж: Издательство Воронежского государственного университета, 1999. С. 44-54.

18. Исторический очерк всеобщего обучения в Нижегородском уезде (полное осуществление школьной сети) в связи с работой земства по народному образованию: Доклад Нижегородского уездного земства Общеземскому съезду по народному образованию. Сост. Н. Н. Иорданский. Нижний Новгород: Издание Нижегородского уездного земства, 1911. 67 с.

19. Статистические сведения по начальному образованию в Российской империи. Вып. III. СПб.: Типография СПб. акционерного общества печатного дела в России Е. Евдокимова, 1902. XLI, 277 с.

20. Первая Всеобщая перепись Российской империи. 1897. Общий свод. Центральная типолитография М. Я. Минкова, 1905. T. 1. XXII, 268, 89 c. T. 2. LX, 417 c.

21. Начальные училища, находящие в ведении Министерства народного просвещения в 1897 году. Ярославль: Школьная комиссия Ярославского губернского земства, 1899. 42, 74 с.

22. Псковская губерния. Начальное народное образование. Псков: Б. и., 1899. 152 с.

23. Начальное образование в Ярославской губернии. 1896/97 учебный год. М.: Типолитография В. Рихтер, 1902. V, 491, LXIII c.

24. Подготовительные работы по введению всеобщего обучения // Журнал Министерства народного просвещения. 1908. № 3. Отдел по народному образованию. С. 1-45.

25. Положение народного образования во Владимирской губернии по исследованию 1910 г. Вып. І. Владимир: Типолитография губернской земской управы, 1911. 254 с.

26. Положение народного образования в Саратовской губернии за время существования земских учреждений. Вып. 11. Саратов: Типография губернского земства, 1894. 384 с.

27. Положение народного образования в Тульской губернии в 1910 г. Краткий обзор. Тула: Типография Е. И. Дружининой, 1911. II, 103 c.

28. Очерки русской культуры XIX века. М.: Издательство Московского университета, 2001. Т. 3. Культурный потенциал общества. 640 с.

29. Слобожанин М. Из истории и опыта земских учреждений в России. СПб.: Издание журнала «Жизнь для всех», 1913. 551 с.

30. Шелгунов Н. В. Очерки русской жизни. СПб.: Издательство О. Н. Поповой, 1895. 1098 стб.

31. Слобожанин М. Школа и жизнь (Из воспоминаний сельского учителя) // Наблюдатель. 1893. № 12. С. $127-151$.

32. Слобожанин М. Школа и жизнь (Из воспоминаний сельского учителя) // Наблюдатель. 1893. № 8. С. $234-307$.

33. Ушинский К. Д. Общий взгляд на возникновение народных школ // Собрание сочинений. Т. 3. М.; Л.: Издательство Академии педагогических наук, 1948. С. 607-625.

34. По поводу сумм, ассигнуемых земскими собраниями разных губерний на начальное народное образование // Журнал Министерства народного просвещения. 1870. № 4. Современная летопись. С. 1-2.

35. Мижуев П. Г. Влияние народного образования на народные богатства, здоровье и нравственность. СПб.: Журнал «Русская школа», 1901. 198 с.

36. Введенский И. Ф. Краткий очерк развития народного образования в Нижегородской губернии (1865-1896 гг.). Нижний Новгород: Нижегородское уездное земство, 1896. 29 с.

37. Н-в. Тернистый путь (Из записок школьного учителя) // Наблюдатель. 1899. № 7. С. 30-45.

38. Шестаков П. Итоги земской деятельности по народному образованию в Нижегородской губернии // Русская школа. 1890. № 6. С. $110-131$.

39. Фальборк Г., Чарнолуский В. Народное образование в России. СПб.: Издательство О. Н. Поповой, 1899. 264 с.

40. Гумп Э. М. Образование и грамотность в глубине России. Воронежская губ. 1885-1897 // Менталитет и аграрное развитие России (XIX-XX вв.). Материалы международной конференции. Москва, 14-15 июня 1994. М.: РОССПЭН, 1996. С. $306-320$. 


\section{Социальная история}

DOI: $10.7256 / 2222-1972.2015 .4 .17036$

41. Рескрипт от 25 декабря 1873 г. // Журнал Министерства народного просвещения. 1874. № 1. С. 3-5.

42. Никольский Г. Начальное образование в Тверской губ. // Школа и жизнь. 1914. № 8. С. 7-9.

43. Книжник И. Земство и народное образование в 1914 г. // Школа и жизнь. 1915. № 1. С. 12-15.

44. Государственный архив Российской Федерации. Ф. 517. Всероссийский союз учителей. Оп. 1. Д. 74.

45. Государственный архив Российской Федерации. Ф. 517. Всероссийский союз учителей. Оп. 1. Д. 116.

46. Очерки истории школы и педагогической мысли народов СССР. Конец XIX - начало XX вв. М.: Педагогика, 1991. 445 с.

47. Объяснительная записка к смете Министерства народного просвещения за 1916 г. // Журнал Министерства народного просвещения. 1916. № 8. С. 159-176.

48. Толстой И. И. Заметки по народному образованию. СПб.: Типография Товарищества М. О. Вольф, 1907.131 с.

49. Толстой И. И. Воспоминания. М.: «Греко-латинский кабинет» Ю. А. Шичалина, 2004. 333 с.

50. Тебиев Б. К. На рубеже веков. Правительственная политика в области образования и общественно-педагогическое движение в России в конце XIX - начале XX вв. М.: Интеллект, 1996. 251 с.

51. О начальных и низших железнодорожных школах // Журнал Министерства народного просвещения. 1907. № 4. Отдел по народному образованию. С. 113-139.

52. Чарнолуский В. И. Вопросы народного образования на Общеземском съезде // Русская школа. 1911. № 10. С. 88-107.

53. Центральный исторический архив Москвы. Ф. 459. Канцелярия попечителя Московского учебного округа. Оп. 4. Т. 4. Д. 5421.

54. Центральный исторический архив Москвы. Ф. 459. Канцелярия попечителя Московского учебного округа. Оп. 4. Т. 4. Д. 6048.

55. Однодневная перепись начальных школ в Империи, произведенная 18.І.1911 г. СПб.: Типография «Экономия», 1913. Вып. 2. 4, 38, 244 с.

56. Однодневная перепись начальных школ в Империи, произведенная 18.I.1911 г. СПб.: Типография «Экономия», 1913. Вып. 11. 2, 34, 135 с.

57. Постановления Первого Общеземского съезда // Сборник постановлений и резолюций всероссийских и областных съездов. Пг., 1915. С. 1-41.

58. Объяснительная записка к отчету государственного контроля по исполнению государственной росписи и финансовых смет за 1911 год. СПб.: Б. и., 1912. 216 с.

59. Объяснительная записка к отчету государственного контроля по исполнению государственной росписи и финансовых смет за 1913. Пг.: Б. и., 1914. VII, 1021, 347 с.

60. Рашин А. Г. Население России за 100 лет (1811-1913 гг.): Статистические очерки. М.: Госстатиздат, 1956. 352 с.

61. Центральный исторический архив Москвы. Ф. 459. Канцелярия попечителя Московского учебного округа. Оп. 4. Т. 4. Д. 6925.

62. Симчера В. М. Развитие экономики России за 100 лет. 1900-2000: Исторические ряды, вековые тренды, периодические циклы. М.: Экономика, 2006. 683 с

\section{References (transliterated):}

1. Veselovskii B. B. Istoriya zemstva za sorok let. SPb.: Izdatel'stvo O. N. Popovoi, 1909. T. 1. 724 s.; T. 2. 703 s.; 1911. T. 3. 710 s.; T. $4.696 \mathrm{~s}$.

2. Chekhov N. V. Narodnoe obrazovanie v Rossii s 60-kh godov XIX veka. M.: Pol'za, 1912. $224 \mathrm{~s}$.

3. Bunakov N. F. Sel'skaya shkola i narodnaya zhizn'. Nablyudeniya i zametki sel'skogo uchitelya // Bunakov N. F. Izbrannye pedagogicheskie sochineniya. M.: Izdatel'stvo Akademii pedagogicheskikh nauk RSFSR, 1953. S. 267-327.

4. Belokonskii I. B. Narodnoe obrazovanie v Orlovskoi gubernii. K 25-letiyu zemskikh uchrezhdenii // Russkaya shkola. 1890 . № 7. S. 112-135.

5. Zvyagintsev E. A. Polveka zemskoi deyatel'nosti po narodnomu obrazovaniyu. M.: Zadruga, 1915. $96 \mathrm{~s}$.

6. Akimov V. Deyatel'nost' Vyatskogo zemstva po narodnomu obrazovaniyu (1865-1906) // Zhurnal Ministerstva narodnogo prosveshcheniya. 1907. № 11. S. 2-46.

7. Akimov V. Deyatel'nost' Simbirskogo zemstva po narodnomu obrazovaniyu. (1866-1900) // Zhurnal Ministerstva narodnogo prosveshcheniya. 1905. № 11. S. 2-35.

8. Milyukov P. N. Ocherki po istorii russkoi kul'tury. Izd. 4-e. SPb.: Redaktsiya zhurnala «Mir bozhii», 1905. Ch. 2. 412 s.

9. Miropol'skii S. I. Shkola i gosudarstvo. Obyazatel'nost' obucheniya v Rossii. SPb.: Tipografiya A. N. Kotomina, 1910. $229 \mathrm{~s}$.

10. Rozhdestvenskii S. V. Istoricheskii obzor deyatel'nosti Ministerstva narodnogo prosveshcheniya. 1802-1902. SPb.: Ministerstvo narodnogo prosveshcheniya, 1902. $785 \mathrm{~s}$.

11. Ocherki istorii shkoly i pedagogicheskoi mysli narodov SSSR vo vtoroi polovine XIX v. M.: Pedagogika, 1976. 599 s.

12. Sludkovskaya I. A. Razvitie narodnoi shkoly na Urale v XIX v. Perm': POIPKRO, 1976. $168 \mathrm{~s}$.

13. Baldin K. E., Ivanov V. V. Zemskie shkoly Ivanovskogo kraya: konets XIX - nachalo XX v. Ivanovo: YuNONA, 2000. $418 \mathrm{s.}$

14. Ivanova N. I. Deyatel'nost' Novotorzhskogo uezdnogo zemstva po razvitiyu narodnogo obrazovaniya v 60-90-e gg. XIX v. // Tverskaya zemlya v proshlom i nastoyashchem: Sbornik nauchnykh trudov. Tver': TGU, 1994. S. 24-36.

15. Stepanskii A. D. Liberal'naya intelligentsiya v obshchestvennom dvizhenii // Istoricheskie zapiski. M.: Nauka, 1983. T. 109. S. 64-94.

16. Sysoeva E. K. Obshchestvennost' i narodnaya shkola v poreformennoi Rossii // Vestnik MGU. Seriya 8. Istoriya. 2002. № 6. S. $16-31$.

17. Yastrebov A. E. Narodnye chteniya v gubernskikh gorodakh Tsentral'noi Rossii v kontse XIX - nachale XX vv. (po materialam Orla, Kurska, Voronezha) // Obshchestvennaya i kul'turnaya zhizn' Tsentral'noi Rossii v XVIII - nachale XX vv.: Sbornik nauchnykh trudov. Voronezh: Izdatel'stvo Voronezhskogo gosudarstvennogo universiteta, 1999. S. 44-54.

18. Istoricheskii ocherk vseobshchego obucheniya v Nizhegorodskom uezde (polnoe osushchestvlenie shkol'noi seti) v svyazi s rabotoi zemstva po narodnomu obrazovaniyu: Doklad Nizhegorodskogo uezdnogo zemstva Obshchezemskomu s"ezdu po narodnomu obrazovaniyu. Sost. N. N. Iordanskii. Nizhnii Novgorod: Izdanie Nizhegorodskogo uezdnogo zemstva, 1911. $67 \mathrm{~s}$. 


\section{Исторический журнал: научные исследования № 4 (28) • 2015}

DOI: $10.7256 / 2222-1972.2015 .4 .17036$

19. Statisticheskie svedeniya po nachal'nomu obrazovaniyu v Rossiiskoi imperii. Vyp. III. SPb.: Tipografiya SPb. aktsionernogo obshchestva pechatnogo dela v Rossii E. Evdokimova, 1902. XLI, $277 \mathrm{~s}$.

20. Pervaya Vseobshchaya perepis' Rossiiskoi imperii. 1897. Obshchii svod. Tsentral'naya tipolitografiya M. Ya. Minkova, 1905. T. 1. XXII, 268, 89 s. T. 2. LX, $417 \mathrm{~s}$.

21. Nachal'nye uchilishcha, nakhodyashchie v vedenii Ministerstva narodnogo prosveshcheniya v 1897 godu. Yaroslavl': Shkol'naya komissiya Yaroslavskogo gubernskogo zemstva, 1899. 42, $74 \mathrm{~s}$.

22. Pskovskaya guberniya. Nachal'noe narodnoe obrazovanie. Pskov: B. i., 1899. $152 \mathrm{s.}$

23. Nachal'noe obrazovanie v Yaroslavskoi gubernii. 1896/97 uchebnyi god. M.: Tipolitografiya V. Rikhter, 1902. V, 491, LXIII c.

24. Podgotovitel'nye raboty po vvedeniyu vseobshchego obucheniya // Zhurnal Ministerstva narodnogo prosveshcheniya. 1908. № 3. Otdel po narodnomu obrazovaniyu. S. 1-45.

25. Polozhenie narodnogo obrazovaniya vo Vladimirskoi gubernii po issledovaniyu 1910 g. Vyp. I. Vladimir: Tipolitografiya gubernskoi zemskoi upravy, 1911. $254 \mathrm{~s}$.

26. Polozhenie narodnogo obrazovaniya v Saratovskoi gubernii za vremya sushchestvovaniya zemskikh uchrezhdenii. Vyp. 11. Saratov: Tipografiya gubernskogo zemstva, 1894. $384 \mathrm{~s}$.

27. Polozhenie narodnogo obrazovaniya v Tul'skoi gubernii v 1910 g. Kratkii obzor. Tula: Tipografiya E. I. Druzhininoi, 1911. II, $103 \mathrm{~s}$.

28. Ocherki russkoi kul'tury XIX veka. M.: Izdatel'stvo Moskovskogo universiteta, 2001. T. 3. Kul'turnyi potentsial obshchestva. $640 \mathrm{~s}$.

29. Slobozhanin M. Iz istorii i opyta zemskikh uchrezhdenii v Rossii. SPb.: Izdanie zhurnala «Zhizn' dlya vsekh», 1913. $551 \mathrm{~s}$.

30. Shelgunov N. V. Ocherki russkoi zhizni. SPb.: Izdatel'stvo O. N. Popovoi, 1895. 1098 stb.

31. Slobozhanin M. Shkola i zhizn' (Iz vospominanii sel'skogo uchitelya) // Nablyudatel'. 1893. № 12. S. 127-151.

32. Slobozhanin M. Shkola i zhizn' (Iz vospominanii sel'skogo uchitelya) // Nablyudatel'. 1893. № 8. S. 234-307.

33. Ushinskii K. D. Obshchii vzglyad na vozniknovenie narodnykh shkol // Sobranie sochinenii. T. 3. M.; L.: Izdatel'stvo Akademii pedagogicheskikh nauk, 1948. S. 607-625.

34. Po povodu summ, assignuemykh zemskimi sobraniyami raznykh gubernii na nachal'noe narodnoe obrazovanie // Zhurnal Ministerstva narodnogo prosveshcheniya. 1870. № 4. Sovremennaya letopis'. S. 1-2.

35. Mizhuev P. G. Vliyanie narodnogo obrazovaniya na narodnye bogatstva, zdorov'e i nravstvennost'. SPb.: Zhurnal «Russkaya shkola», 1901. $198 \mathrm{~s}$.

36. Vvedenskii I. F. Kratkii ocherk razvitiya narodnogo obrazovaniya v Nizhegorodskoi gubernii (1865-1896 gg.). Nizhnii Novgorod: Nizhegorodskoe uezdnoe zemstvo, 1896. $29 \mathrm{~s}$.

37. N-v. Ternistyi put' (Iz zapisok shkol'nogo uchitelya) // Nablyudatel'. 1899. № 7. S. 30-45.

38. Shestakov P. Itogi zemskoi deyatel'nosti po narodnomu obrazovaniyu v Nizhegorodskoi gubernii // Russkaya shkola. 1890 . № 6. S. 110-131.

39. Fal'bork G., Charnoluskii V. Narodnoe obrazovanie v Rossii. SPb.: Izdatel'stvo O. N. Popovoi, 1899. 264 s.

40. Gump E. M. Obrazovanie i gramotnost' v glubine Rossii. Voronezhskaya gub. 1885-1897 // Mentalitet i agrarnoe razvitie Rossii (XIX-XX vv.). Materialy mezhdunarodnoi konferentsii. Moskva, 14-15 iyunya 1994. M.: ROSSPEN, 1996. S. 306-320.

41. Reskript ot 25 dekabrya 1873 g. // Zhurnal Ministerstva narodnogo prosveshcheniya. 1874. № 1. S. 3-5.

42. Nikol'skii G. Nachal'noe obrazovanie v Tverskoi gub. // Shkola i zhizn'. 1914. № 8. S. 7-9.

43. Knizhnik I. Zemstvo i narodnoe obrazovanie v 1914 g. // Shkola i zhizn'. 1915. № 1. S. 12-15.

44. Gosudarstvennyi arkhiv Rossiiskoi Federatsii. F. 517. Vserossiiskii soyuz uchitelei. Op. 1. D. 74.

45. Gosudarstvennyi arkhiv Rossiiskoi Federatsii. F. 517. Vserossiiskii soyuz uchitelei. Op. 1. D. 116.

46. Ocherki istorii shkoly i pedagogicheskoi mysli narodov SSSR. Konets XIX - nachalo XX vv. M.: Pedagogika, 1991. $445 \mathrm{~s}$.

47. Ob"yasnitel'naya zapiska k smete Ministerstva narodnogo prosveshcheniya za 1916 g. // Zhurnal Ministerstva narodnogo prosveshcheniya. 1916. № 8. S. 159-176.

48. Tolstoi I. I. Zametki po narodnomu obrazovaniyu. SPb.: Tipografiya Tovarishchestva M. O. Vol'f, 1907. $131 \mathrm{~s}$.

49. Tolstoi I. I. Vospominaniya. M.: «Greko-latinskii kabinet» Yu. A. Shichalina, 2004. $333 \mathrm{~s}$.

50. Tebiev B. K. Na rubezhe vekov. Pravitel'stvennaya politika v oblasti obrazovaniya i obshchestvenno-pedagogicheskoe dvizhenie v Rossii v kontse XIX - nachale XX vv. M.: Intellekt, 1996. $251 \mathrm{s.}$

51. O nachal'nykh i nizshikh zheleznodorozhnykh shkolakh // Zhurnal Ministerstva narodnogo prosveshcheniya. 1907. № 4. Otdel po narodnomu obrazovaniyu. S. 113-139.

52. Charnoluskii V. I. Voprosy narodnogo obrazovaniya na Obshchezemskom s"ezde // Russkaya shkola. 1911. № 10. S. 88-107.

53. Tsentral'nyi istoricheskii arkhiv Moskvy. F. 459. Kantselyariya popechitelya Moskovskogo uchebnogo okruga. Op. 4. T. 4. D. 5421.

54. Tsentral'nyi istoricheskii arkhiv Moskvy. F. 459. Kantselyariya popechitelya Moskovskogo uchebnogo okruga. Op. 4. T. 4. D. 6048.

55. Odnodnevnaya perepis' nachal'nykh shkol v Imperii, proizvedennaya 18.I.1911 g. SPb.: Tipografiya «Ekonomiya», 1913. Vyp. 2. $4,38,244 \mathrm{~s}$.

56. Odnodnevnaya perepis' nachal'nykh shkol v Imperii, proizvedennaya 18.I.1911 g. SPb.: Tipografiya «Ekonomiya», 1913. Vyp. 11. $2,34,135$ s.

57. Postanovleniya Pervogo Obshchezemskogo s"ezda // Sbornik postanovlenii i rezolyutsii vserossiiskikh i oblastnykh s"ezdov. Pg., 1915. S. 1-41.

58. Ob"yasnitel'naya zapiska k otchetu gosudarstvennogo kontrolya po ispolneniyu gosudarstvennoi rospisi i finansovykh smet za 1911 god. SPb.: B. i., 1912. 216 s.

59. Ob"yasnitel'naya zapiska k otchetu gosudarstvennogo kontrolya po ispolneniyu gosudarstvennoi rospisi i finansovykh smet za 1913. Pg.: B. i., 1914. VII, 1021, 347 s.

60. Rashin A. G. Naselenie Rossii za 100 let (1811-1913 gg.): Statisticheskie ocherki. M.: Gosstatizdat, 1956. 352 s.

61. Tsentral'nyi istoricheskii arkhiv Moskvy. F. 459. Kantselyariya popechitelya Moskovskogo uchebnogo okruga. Op. 4. T. 4. D. 6925.

62. Simchera V. M. Razvitie ekonomiki Rossii za 100 let. 1900-2000: Istoricheskie ryady, vekovye trendy, periodicheskie tsikly. M.: Ekonomika, 2006. $683 \mathrm{~s}$. 